\title{
PHYSICO-CHEMICAL STUDY CONCERNING ATMOSPHERIC PARTICULATE MATTER HAZARD
}

\author{
IOAN PETEAN ${ }^{a}$, AURORA MOCANU ${ }^{a}$, \\ GERTRUD-ALEXANDRA PĂLTINEAN ${ }^{a}$, RALUCA ŢĂRCAN ${ }^{a}$, \\ DANA FLORINA MUNTEAN ${ }^{\mathrm{b}}$, LIANA MUREŞAN ${ }^{\mathrm{b}}$, GEORGE ARGHIR $^{\mathrm{c} *}$, \\ MARIA TOMOAIA COTIŞEL ${ }^{\mathrm{a}, \mathrm{d}}$
}

\begin{abstract}
The particulate matter (PM) from the atmosphere is able to penetrate in the respiratory system presenting several health risks such as acute respiratory items, allergic issues, and chronic risks such as silicosis and asthma. PM from atmosphere is classified by diameter as PM10 particles with aerodynamic diameter up to $10 \mu \mathrm{m}$, PM2.5 - particles with aerodynamic diameter up to $2.5 \mu \mathrm{m}$, and PM1 - particles with aerodynamic diameter up to $1 \mu \mathrm{m}$. The first major PM source is the street dust (SD) which induces mineral fraction into the atmosphere such as: quartz, kaolinite, calcite, muscovite, and goethite. The second PM source is the pollen from several species like Tilia Cordata, Sambucus Nigra, Jasminus Communis, Rosaceae Family, Lilium Candidum, and Brassica Rapa, during later spring and early summer. Elements from both sources were found in PM samples collected from atmosphere: sedimentary particles, PM10 and PM2.5. In vivo experiments show that PM10 affects upper respiratory pathways such as nasal cavity and pharynges meanwhile PM2.5 was found in the expectoration matter from tracheal area. These studies reveal that 5 minutes of exposure at a concentration of $125 \mu \mathrm{gg} / \mathrm{m}^{3}$ conducts to formation of severe deposits on respiratory mucosa.
\end{abstract}

Keywords: PM 10, PM 2.5, hazard

\footnotetext{
a Babeş-Bolyai University, Faculty of Chemistry and Chemical Engineering, Arany Janos Str., No. 11, RO-400084 Cluj-Napoca, Romania.

b Environmental Protection Agency Cluj, Calea Dorobanţilor Str., No. 99, RO-400609, ClujNapoca, Romania.

${ }^{\mathrm{C}}$ Technical University of Cluj - Napoca, Faculty of Materials and Environment Engineering, Muncii Ave., No. 103 -105, RO-400641 Cluj - Napoca, Romania.

d Academy of Romanian Scientists, 54 Splaiul Independentei, 050094, Bucharest, Romania

*Correspondent author: georgearghir@hotmail.com
} 


\section{INTRODUCTION}

Particulate matters (PM) dispersed in the atmosphere represent a great concern for the human health due to their ability to be inhaled [1 - 4]. Such particles are trapped by the respiratory system mucosa to prevent their penetration in the lungs. Thus, the hazard is a matter of particle size related to the penetration depth in the respiratory system. PM10 is usually trapped into the nose cavity and nasal passages; meanwhile PM2.5 is able to be inhaled down to trachea and primary bronchi $[5,6]$. The effect of inhaled particles leads to specific affections such as: acute pathologies including allergies, inflammations and respiratory insufficiency [7, 8]. Longer exposure to inhaled PM leads to the chronic affections such as: silicosis, lung cancer and autoimmune responses due to the disturbed neuronal activity of receptors sensing the presence of the particles [9 -12].

Recent developed studies related to the atmospheric PM evidence the silicate particles occurrence due to the environmental condition in the urban area [13 - 15]. Such particles could be very harmful if inhaled. The aim of this paper is to establish PM10 and PM2.5 ability to be inhaled and to identify which kind of particles are able to penetrate in the respiratory system. Therefore, we consider some in vivo tests for the identification of those particles.

\section{RESULTS AND DISCUSSION}

The data in literature state that street dust (SD) is the most important source of atmospheric PM [13]. Therefore, we select a complex area situated in Dâmboviţei Street, Cluj - Napoca, Romania, for present study. It features a street with average car traffic, around 15 cars per minute, bordered with complex environment containing decayed soils and green areas (e.g. Dâmboviţei Park and Expo Transilvania Park) containing various plant species. The representative SD sample for this environment was physico - chemical investigated.

The minerals were identified by XRD analysis, Figure 1. Resulted XRD pattern has very well-developed peaks proving the cristalinity of SD sample. 


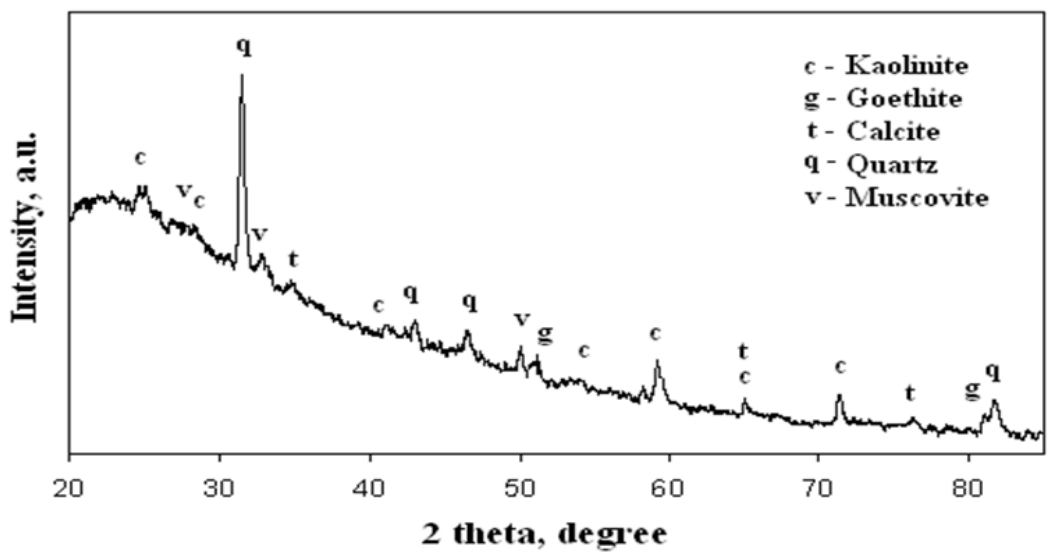

Figure 1. The X-ray spectrum for SD sample collected from Dâmboviţei Street.

The dominant mineral is quartz followed by clay mixture (e.g. kaolinite and muscovite), calcite and goethite are the last minerals. XRD data were correlated with mineralogical microscopy performed in cross polarized light, Figures 2.

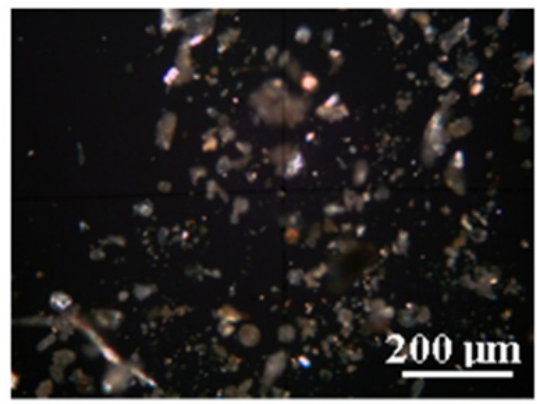

a

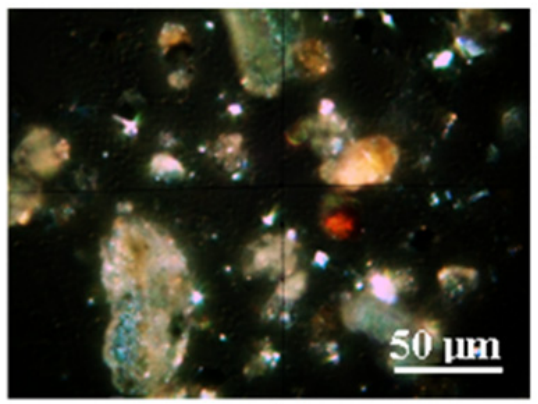

b

Figure 2. SD sample collected from Dâmboviţei Street observed in cross polarized light: a) low magnification and b) high magnification.

A wide mixture of particles is observed at low magnification, Figure $2 a$, their size ranges from small microscopic level to grosser particles having over $100 \mu \mathrm{m}$ diameter. At high magnification, Figure $2 \mathrm{~b}$, particles are seen better, each mineral species having its own specific color. The XRD and mineralogical microscopy data resulted for the SD sample are summarized in Table 1. 
I. PETEAN, A. MOCANU, G. PĂLTINEAN, R. Ţ̆RCAN, D. MUNTEAN, L. MUREŞAN, G. ARGHIR, M. COTIŞEL

Table 1. Components properties of SD sample

\begin{tabular}{|c|c|c|c|c|c|}
\hline Component & Quartz & Kaolinite & Muscovite & Calcite & Goethite \\
\hline Formula & $\mathrm{SiO}_{2}$ & $\mathrm{Al}_{2} \mathrm{Si}_{2} \mathrm{O}_{5}(\mathrm{OH})_{4}$ & $\mathrm{KAl}_{2}\left(\mathrm{AlSi}_{3} \mathrm{O}_{10}\right)(\mathrm{F}, \mathrm{OH})_{2}$ & $\mathrm{CaCO}_{3}$ & $\mathrm{aFeO}(\mathrm{OH})$ \\
\hline $\begin{array}{c}\text { Particle size } \\
\text { range, } \mu \mathrm{m}\end{array}$ & $2-100$ & $1-20$ & $1-25$ & $10-40$ & $5-50$ \\
\hline $\begin{array}{c}\text { Color in cross } \\
\text { polarized light }\end{array}$ & $\begin{array}{c}\text { Green - } \\
\text { gray }\end{array}$ & $\begin{array}{c}\text { White- } \\
\text { Blue }\end{array}$ & Pink & $\begin{array}{c}\text { Yellow- } \\
\text { brown }\end{array}$ & $\begin{array}{c}\text { Reddish - } \\
\text { brown }\end{array}$ \\
\hline
\end{tabular}

The SD sample has mineral components derived from local decayed soils, representing a fingerprint of the investigated area. All SD particles could be suspended in the atmosphere due to various environmental factors such as natural air currents (affected by regional climate) and anthropogenic factors such as car traffic and industrial activities [16, 17]. Their ascension into the atmosphere depends on the particles physical properties, mainly their diameter. All SD minerals have small micro particles which are able to be lifted in the air.

Minerals are not only one source of particulate matters, pollen from various vegetal species is often found in the atmosphere during April and May. Such organic particles could be hazardous for human health due to the allergenic issues. Therefore, the pollen was extracted from fresh flowers collected during April and May 2017 from the adjacent area of Dâmboviţei Street. These samples were investigated in transmitted light, Figure 3.

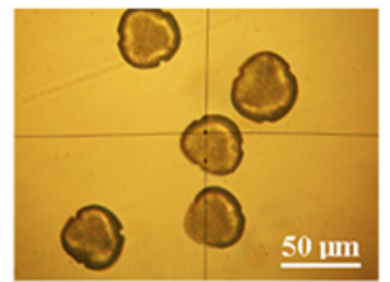

a

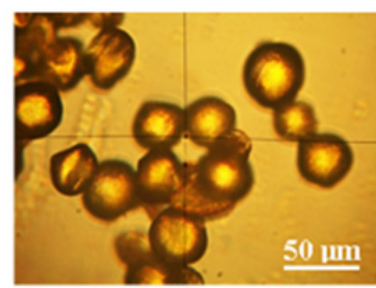

d

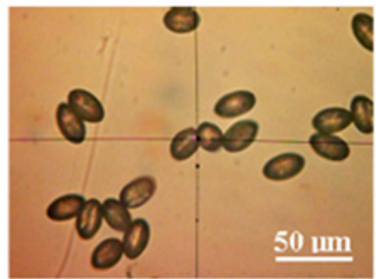

b

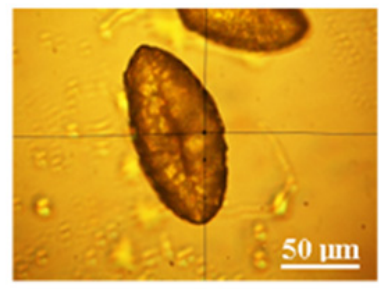

e

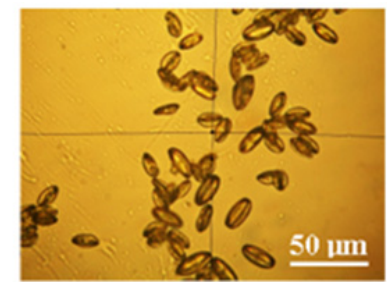

c

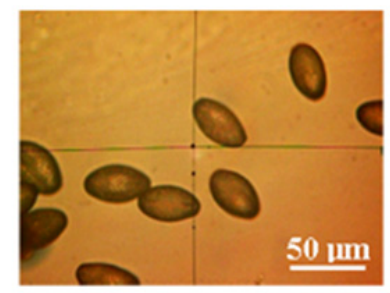

f

Figure 3. Pollen samples collected from Dâmboviţei Street area observed in transmitted light light: a) Tilia Cordata, b) Sambucus Nigra, c) Jasminus Communis, d) Rosaceae Family, e) Lilium Candidum, and f) Brassica Rapa. 
The quantitative measurements performed on images in Figure 3 are centralized and systematized in Table 2 . The obtained values related to pollen shape are in good agreement with pallinological databases.

Table 2. Pollen particles characteristics

\begin{tabular}{|c|c|c|c|c|c|c|}
\hline Plant & Tilia & Sambucus & Jasminus & Rosa & Lilium & Brassica \\
\hline Shape & $\begin{array}{c}\text { sub- } \\
\text { triangular }\end{array}$ & elongated & elongated & round & elongated & elongated \\
\hline Length, $\mu \mathrm{m}$ & \multirow[b]{2}{*}{35} & 25 & 20 & \multirow[b]{2}{*}{$25-30$} & 125 & 35 \\
\hline $\begin{array}{l}\text { Diameter, } \\
\text { Mm }\end{array}$ & & 10 & 5 & & 50 & 15 \\
\hline
\end{tabular}

Pollen particles from Sambucus Nigra and Jasminus Communis presents characteristic dimensions for PM10 being the most susceptible to be inhaled from all investigated range. The most inoffensive is the Lilium Candidum pollen due to its larger size and sticky surface.

Floating particles (FP) from atmosphere represents the most heterogenic particulate matter sample containing all kind of solids suspended in air due to various conditions, that's why some authors refer to total sedimentary particles $[18,19]$. The maximum accepted level of FP emission is $17 \mathrm{~g} / \mathrm{m}^{2} / \mathrm{h}$ according to Romanian and UE laws. The representative FP sample collected with the Automatic Station of Air Quality Monitoring was subjected to the XRD analysis, Figure 4a.

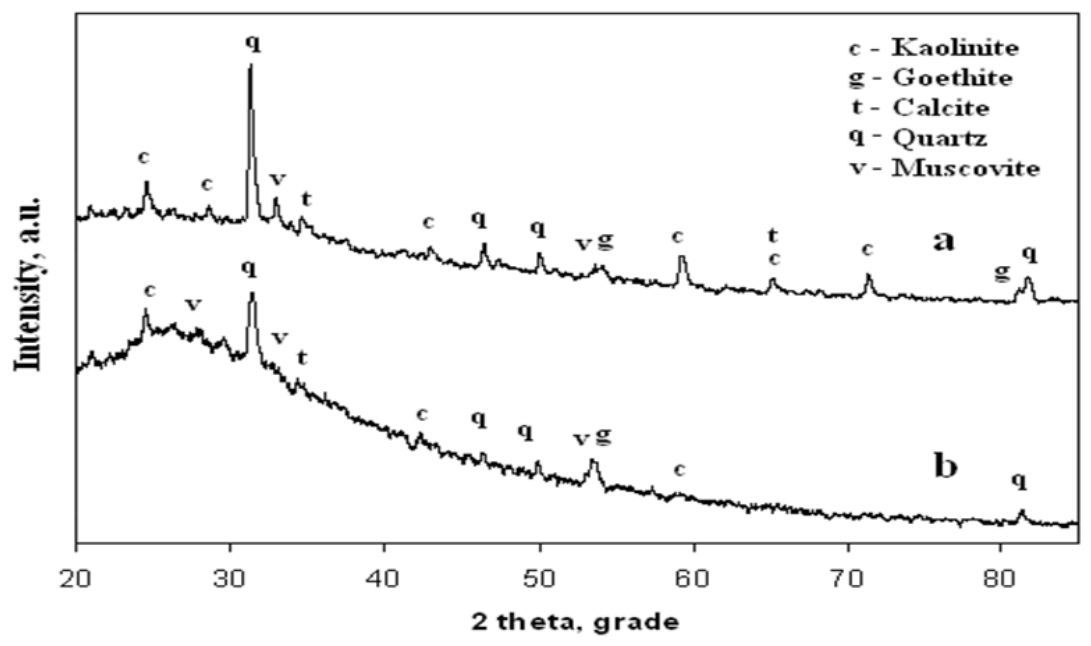

Figure 4. The X-ray spectra for FP (a) and PM10 (b) collected from Dâmboviţei Street with Automatic Station for Air Quality Monitoring. 
It features well developed peaks proving the high level of cristallinity of FP sample, Figure 4a. A great similitude with SD sample is observed, Figure 4b. Minerals found in FP sample are the same as in SD: quartz, kaolinite and muscovite, calcite and goethite. Optical microscopy performed on FP reveals two areas of interest, Figure 5.

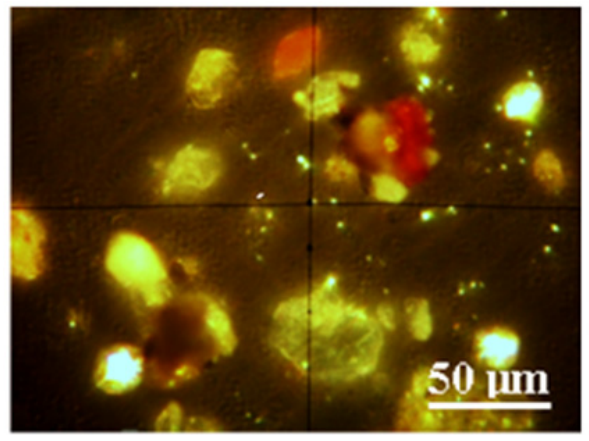

a

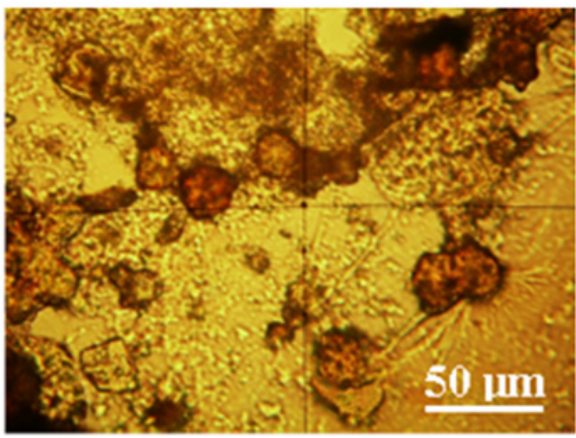

b

Figure 5. FP sample collected from Dâmboviţei Street: a) reach mineral area observed in cross polarized light and b ) organic reach area observed in transmitted light.

The first is the reach mineral area, Figure 5a, where appear fine particles with tabular aspect like kaolinite and muscovite [20, 21] mixed up with a various mixture of quartz calcite and goethite. A dimensional hierarchy is observed: clay particles are present mostly in PM2.5 area meanwhile quartz and calcite are rather found in PM10 category, Table 3.

Table 3. Components properties of FP sample

\begin{tabular}{|c|c|c|c|c|c|}
\hline Component & Quartz & Kaolinite & Muscovite & Calcite & Goethite \\
\hline Formula & $\mathrm{SiO}_{2}$ & $\mathrm{Al}_{2} \mathrm{Si}_{2} \mathrm{O}_{5}(\mathrm{OH})_{4}$ & $\mathrm{KAl}_{2}\left(\mathrm{AlSi}_{3} \mathrm{O}_{10}\right)(\mathrm{F}, \mathrm{OH})_{2}$ & $\mathrm{CaCO}_{3}$ & $\mathrm{aFeO}(\mathrm{OH})$ \\
\hline $\begin{array}{c}\text { Particle size } \\
\text { range, } \mu \mathrm{m}\end{array}$ & $2-50$ & $1-20$ & $1-25$ & $10-40$ & $5-60$ \\
\hline $\begin{array}{c}\text { Color in } \\
\text { cross } \\
\text { polarized } \\
\text { light }\end{array}$ & $\begin{array}{c}\text { Green - } \\
\text { gray }\end{array}$ & $\begin{array}{c}\text { White- } \\
\text { blue }\end{array}$ & Pink & $\begin{array}{c}\text { Yellow- } \\
\text { brown }\end{array}$ & $\begin{array}{c}\text { Reddish - } \\
\text { brown }\end{array}$ \\
\hline $\begin{array}{c}\text { Particle } \\
\text { shape }\end{array}$ & round & tabular & tabular & round & elongated \\
\hline
\end{tabular}


The second is organic reach area, Figure $5 \mathrm{~b}$. A lot of organic matter is situated in micro-scaled conglomerates, but there are a few distinct pollen grains evidenced. Their shape and size is altered by the FP collecting method which uses sedimentation in bi-distilled water, most likely they are Tillia Cordata or Sambucus Nigra grains. This proves the importance of pollen as PM source during spring and early summer. It results that FP sample is SD lifted in the atmosphere combined with pollen from the inblossom flowers in April and May 2017.

PM10 fraction contains also similar minerals like in SD and FP, fact evidenced by the pattern in Figure $4 \mathrm{~b}$. The diffraction peaks are no longer so well developed due to the smaller size of the diffractant particles. Quartz is the dominant mineral, proving that PM is mostly silica, followed by the clay mixture. The mineral arrangement in PM10 is observed by SEM imaging in Figure 6a: where several quartz particles having the range of $2.5-10 \mu \mathrm{m}$ diameter surrounded by smaller particles which are supposed to be clay. Certain evidences were obtained by EDX analysis, Table 4. The major elements in the PM10 composition are Si and O, fact in good agreement with XRD information. Presence of significant amount of $\mathrm{Al}, \mathrm{K}$, and $\mathrm{Mg}$ certify the presence of clay particles into the PM 10 sample. Lower amount of $C$ found in PM10 could be related by the traces of calcite found in XRD pattern and possibly to belong to some organic features.

PM2.5 shape is revealed in the SEM image, Figure 6b. There is a complex conglomerate based on lamellar - tabular particles having sizes below $2.5 \mu \mathrm{m}$. There are also found some rounded particles having typical aspect for grinded quartz. Particles shape and distribution in PM2.5 proves their origin in SD.

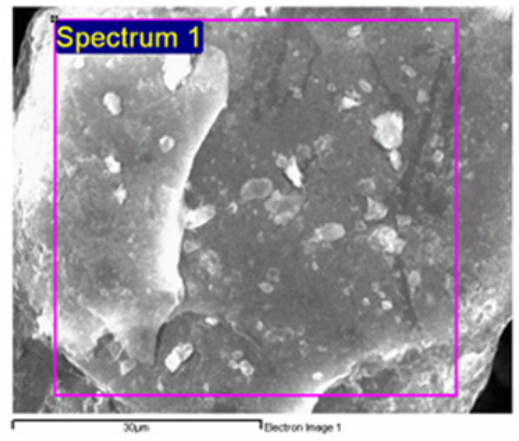

a

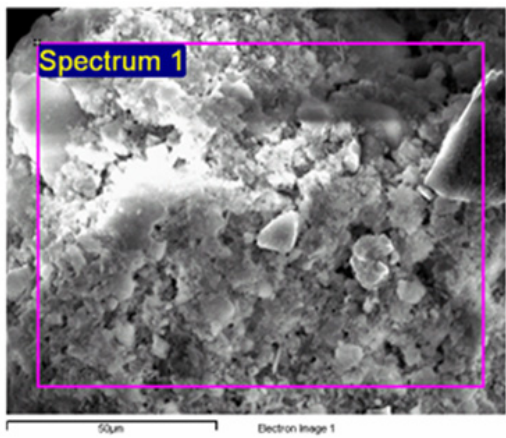

b

Figure 6. SEM images for particulate matters: a) PM10 and b) PM2.5. 
PM2.5 was subjected also to the EDX analysis, results being displayed in Table 4. A significant amount of $\mathrm{Al}$ and $\mathrm{K}$ was observed proving the predominance of clay particles instead quartz ones. The amount of $C$ is increased than in PM10 sample, fact sustained by traces of calcite (around of 1.38 wt. \% Ca) and organic amorphous carbon.

Table 4. Elemental composition for PM10 and PM2.5 resulted from EDX

\begin{tabular}{|l|c|c|c|c|}
\hline \multirow{2}{*}{ Element } & \multicolumn{2}{|c|}{ PM10 } & \multicolumn{2}{c|}{ PM2.5 } \\
\cline { 2 - 5 } & weight \% & atomic \% & weight \% & atomic \% \\
\hline $\mathrm{C}$ & 2.86 & 4.62 & 13.04 & 19.99 \\
\hline $\mathrm{O}$ & 56.27 & 68.27 & 55.77 & 64.18 \\
\hline $\mathrm{Mg}$ & 1.54 & 1.23 & 0.61 & 0.46 \\
\hline $\mathrm{Al}$ & 14.52 & 10.45 & 12.08 & 7.04 \\
\hline $\mathrm{Si}$ & 17.31 & 11.96 & 5.09 & 3.34 \\
\hline $\mathrm{S}$ & - & - & 0.25 & 0.14 \\
\hline $\mathrm{K}$ & 5.65 & 2.80 & 10.39 & 4.06 \\
\hline $\mathrm{Ti}$ & 0.52 & 0.21 & - & - \\
\hline $\mathrm{Ca}$ & - & - & 1.39 & 0.33 \\
\hline $\mathrm{Fe}$ & 1.33 & 0.46 & 1.38 & 0.46 \\
\hline Total & 100.00 & 100.00 & 100.00 & 100.00 \\
\hline
\end{tabular}

EDX analysis confirms the reach mineral composition of PM formed in Dâmboviţei street area containing minerals with hazardous features which if are inhaled could lead to acute respiratory affections and to silicosis at longer term of exposure. The positive aspect revealed by EDX is the lack of heavy metals and or radioactive isotopes in PM10 and PM2.5 samples. This situation decreases the hazard because lack of carcinogenic elements.

Another aspect connected to the respiratory health is the emission level of each PM pollutant category. The data measured from the atmosphere with the Automatic Air Quality Monitoring Station are displayed in Table 5.

Table 5. PM emission level in Dâmboviţei Street for April and May 2017

\begin{tabular}{|c|c|c|c|}
\hline \multicolumn{2}{|c|}{ Emission type } & April 2017 & May 2017 \\
\hline \multirow{2}{*}{$\begin{array}{c}\mathrm{PM} 2.5, \\
\mu \mathrm{g} / \mathrm{m}^{3}\end{array}$} & minim & 5.43 & 12.32 \\
\cline { 2 - 4 } & maxim & 24.65 & 23.75 \\
\cline { 2 - 4 } $\mathrm{PM} 10$, & average & 11.45 & 18.05 \\
\cline { 2 - 4 }$\mu \mathrm{g} / \mathrm{m}^{3}$ & minim & 2.35 & 7.61 \\
\cline { 2 - 4 } & maxim & 42.01 & 42.24 \\
\hline $\begin{array}{c}\mathrm{FP}, \\
\mathrm{g} / \mathrm{m}^{2} / \mathrm{month}\end{array}$ & average & 18.18 & 21.44 \\
\hline
\end{tabular}


FP emission level is situated in the safe range, far below maximum limit of $17 \mathrm{~g} / \mathrm{m}^{2} /$ month. The average values recorded for April and May 2017 for PM2.5 and PM10 are far below the maximum accepted value. This is due to the relatively humid weather related with a good environmental management applied in the street.

The most humid days with the lowest car traffic lead to the lower values recorded, while the driest days with high car traffic lead to the higher values recorded. Only two limits overtake at PM10 were recorded: 42.01 $\mu \mathrm{g} / \mathrm{m}^{3}$ on 27 April 2017 and $42.24 \mu \mathrm{g} / \mathrm{m}^{3}$ on 12 May 2017. These overtakes do not generate hazard because of their low excess of PM 10 situated around $2 \mu \mathrm{g} / \mathrm{m}^{3}$, and happened only once per month.

Nanoparticles from aqueous dispersion were transferred onto solid substrate (e.g. glass slide) by vertical adsorption [22 - 26]. The deposited film was investigated by AFM resulting the image in Figure 7 . The film topography is observed in Figure 7a, the deposited layer is uniform and nanoparticles are well individualized. Cross section in Figure $7 \mathrm{~b}$ allows calculating the average diameter of nanoparticles which is situated around $30 \mathrm{~nm}$.

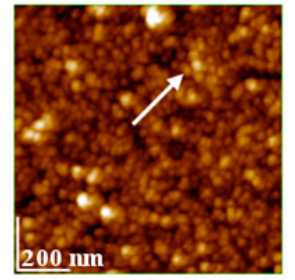

a

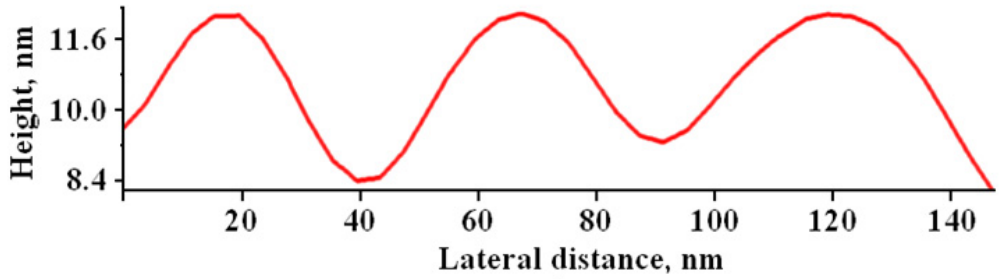

b

Figure 7. AFM images for nanoparticles derived from PM2.5.

Nanoparticles presence in the PM2.5 sample is a risk factor due to their ability to penetrate tissues such as pulmonary alveoli. Fortunately, nanoparticles have low ability to travel alone into the atmosphere because of their high coalescence tendency. Such coalescence is proved by the formation of nanoparticles clusters observed in AFM images, Figure 7. They are also very sticky and are expected to be trapped into mucus immediately after they are inhaled.

In vivo exposure to the normal atmosphere (e.g. PM level below 40 $\mu \mathrm{g} / \mathrm{m}^{3}$ ) does not affect the nasal mucosa, or the mucus from trachea. It is clearly observed in cross polarized light Figures 8a and 8d: only organic compounds of the mucus are observed with no trace of mineral particles. 
At an exposure of 5 minutes to a polluted air with PM10 level around of $125 \mu \mathrm{g} / \mathrm{m}^{3}$ leads to mineral deposits of PM10 in nose mucus consisting mainly in quartz and fewer clay particles, Figure $8 \mathrm{~b}$. The expectoration product contains some PM2.5 particles consisting in kaolinite and muscovite as seen in Figure 8e. The exposure to a polluted air with PM10 level around of $200 \mu \mathrm{g} / \mathrm{m}^{3}$ for 5 minutes leads to massive deposits of PM10 into the nose mucus containing mainly quartz particles followed by calcite and goethite, Figure 8c.

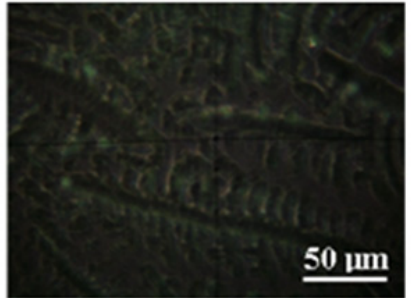

a

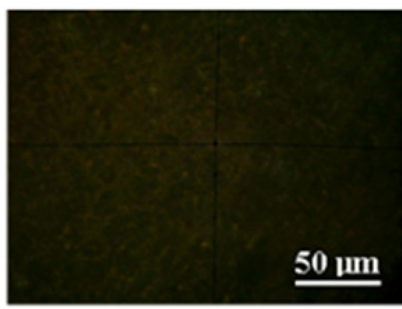

d

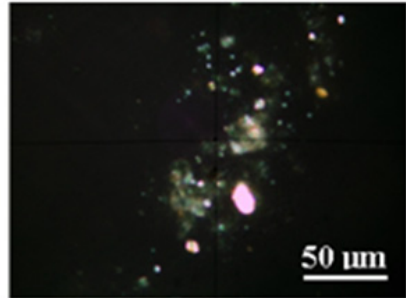

b

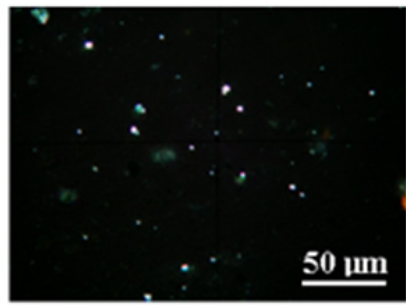

e

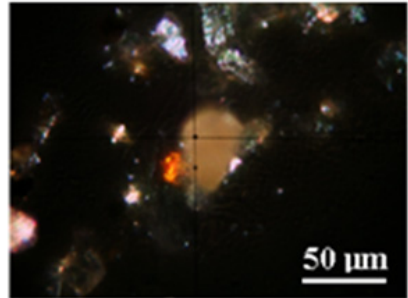

c

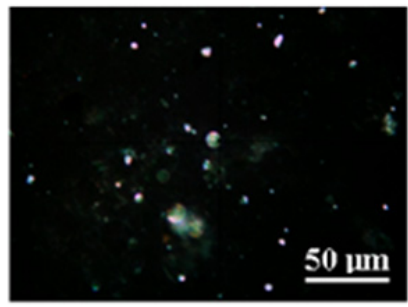

f

Figure 8. Cross polarized light images for in vivo experiment: Nose mucus: a) normal atmosphere, b) polluted atmosphere up to $125 \mu \mathrm{g} / \mathrm{m}^{3}$

PM10, and c) polluted atmosphere up to $200 \mu \mathrm{g} / \mathrm{m}^{3}$; Expectoration product: d) normal atmosphere, e) polluted atmosphere up to $125 \mu \mathrm{g} / \mathrm{m}^{3}$ PM10, and f) polluted atmosphere up to $200 \mu \mathrm{g} / \mathrm{m}^{3}$.

Significant mineral deposits are found in the expectoration product where PM2.5 consisting in clay particles is found predominantly, Figure 8f. There are found also some PM10 particles with quartz aspect, which means a severe penetration of PM into the respiratory system. 


\section{CONCLUSIONS}

The analysis performed in present article proves that SD is the major source of PM in the atmosphere in environmental conditions from Dâmboviţei Street, Cluj - Napoca. The minerals from SD are found in FP sample: quartz as dominant mineral followed by clay mixture with kaolinite and muscovite, calcite and goethite. Pollen was found in FP sample, proving that pollen could be considered as PM which could affect respiratory system especially in allergic affections. PM10 contains mainly quartz particles meanwhile PM2.5 contains kaolinite and muscovite predominantly. Such composition depends on the investigated specific area; some other sites could report other compositions. AFM imaging reveals some nanoparticles in PM2.5.

The minerals in PM10 and PM2.5 could be very hazardous for the respiratory system, if the standard limit is exceeded and the exposure time is long enough in vivo experiments. A short exposure at an intense dose of PM leads to an acute respiratory affection, and chronic affections could appear if exposure is extended for long time.

The air monitoring data shows that the PM emissions in the Dâmboviţei Street area are below standard limit and no hazard risk appears if the environmental condition is maintained.

\section{EXPERIMENTAL SECTION}

The experimental area is situated in Dâmboviţei Street, Cluj - Napoca. The SD samples were collected weekly during April and March 2017. Each week was taken 10 grams of SD and mixed together to obtain an average representative sample of SD. Dâmboviţei Street has a lot of vegetal species which flowers during April and May. Therefore, the resulted pollen could emerge in the atmosphere like PM. Pollen from Tilia Cordata, Sambucus Nigra, Jasminus Communis, Rosaceae Family, Lilium Candidum, and Brassica Rapa was collected and investigated.

PM samples: FP, PM10, and PM2.5 were collected using Automatic Air monit oring Station from Environmental Protection Agency of ClujNapoca, and their level of emission in the atmosphere was monitored during April and May 2017 and the results were centralized.

In vivo experiment consists in a human subject (volunteer agreement) exposed for 5 minutes to normal atmosphere, average polluted atmosphere (aprox. $125 \mu \mathrm{g} / \mathrm{m}^{3}$ of PM10), and high polluted atmosphere (up to $200 \mu \mathrm{g} / \mathrm{m}^{3}$ of PM10). The polluted atmosphere was produced by street dust agitation with an air blower in the Dâmboviţei Street area. Nose mucus and expectoration product was collected after each exposure. The exposures were effectuated in different days to avoid the cumulative effect on the subject. 
The X-ray diffraction analysis was performed on a DRON 3 diffractometer equipped with data acquisition module and MATMEC VI.0 soft. A monochrome $\mathrm{Co}_{\mathrm{k} \alpha}$ radiation was used for all $\mathrm{X}$ ray spectra. The mineral identification was effectuated using MATCH $1.0 \mathrm{X}$ - ray standard data base from Crystal Impact co.

Optical microscopy was performed on a Laboval 2 microscope produced by Karl Zeiss Jena equipped with digital capture Kodak $10 \mathrm{Mpx}$ camera. Quantitative analysis on the optical microphotographs was done using the Image $\mathrm{J}$ professional soft as freeware resource from National Institutes of Health USA.

SEM microscopy associated with EDX analysis was performed on a Jeol JSM 5600 LV microscope in secondary electrons imaging mode coupled with Everhart Thornley detector for EDX analysis

Samples for AFM investigation were prepared according to the data in literature [27 - 34]. The AFM investigation was performed on a Jeol JSPM 4210 microscope in tapping mode using NSC 15 cantilever. Topography, phase, and amplitude images were acquired simultaneously and were processed into the standard manner using Win SPM 2.0 processing soft.

\section{REFERENCES}

1. L.A. Jimoda, Facta Universitatis, Series: Working and Living Environmental Protection, 2012, 9 (1), 27.

2. J.S. Le Blond, S. Woskie, C.J. Horwell, B.J. Williamson, Atmospheric Environment, 2017, 149, 34.

3. W.C. Lo, R.H. Shie, C.C. Chan, H.H. Lin, Journal of the Formosan Medical Association, 2017, 116, 32.

4. M.R. Perrone, S. Becagli, J.A. Garcia Orza, R. Vecchi, A. Dinoi, R. Udisti, M. Cabello, Atmospheric Environment, 2013, 71, 176.

5. K.H. Kim, E. Kabir, S. Kabir, Environment International, 2015, 74, 136.

6. J. Londhal, J. Pagels, E. Swietlicki, J. Zhou, M. Ketzel, A. Massling, M. Boghard, Aerosol Science, 2006, 37, 1152.

7. Q. Xu, S. Wang, Y. Guo, C. Wang, F. Huang, X. Li, Q. Gao, L. Wu, L. Tao, J. Guo, W. Wang, X. Guo, Environmental Pollution, 2017, 220, 317.

8. M. Watanabe, H. Noma, J. Kurai, H. Sano, D. Hantan, M. Ueki, H. Kitano, E. Shimizu, Allergology International, 2017, 66, 52.

9. A.C. Güngen, Y. Aydemir, H. Çoban, H. Düzenli, C. Tasdemir, Respiratory Medicine Case Reports, 2016, 18, 93.

10. A.G. Cohen, F. Romero Ruperto, F.J. G. Sendra, M.J. Sánchez GarcíaAltares, M.L. Parra Gordoc, Medicina General y de Familia, 2016, 5 (4), 169.

11. M. Tsugita, N. Morimoto, M. Tashiro, K. Kinoshita, M. Nakayama, Cell Reports, 2017, 18, 1298. 
12. P. Solaimani, A. Saffari, C. Sioutas, S.C. Bondy, Neuro Toxicology, 2017, 58, 50.

13. G.A. Păltinean, I. Petean, G. Arghir, D.F. Muntean, L.-D. Boboş, M. TomoaiaCotişel, Particulate Science and Technology, 2016, 34 (5), 580.

14. G.A. Păltinean, I. Petean, G. Arghir, D.F. Muntean, M. Tomoaia-Cotişel, Revista de chimie, 2016, 67 (6), 1118.

15. D.F. Muntean, D. Ristoiu, G. Arghir, R.F. Campean, I. Petean, Carpathian Journal of Earth and Environmental Sciences, 2012, 7 (3), 175.

16. S.S. Ram, R.V. Kumar, P. Chaudhuri, S. Chanda, S.C. Santra, M. Sudarshan, A. Chakraborty, Ecological Indicators, 2014, 36, 334.

17. L. Makra, I. Ionel, Z. Csépe, I. Matyasovszky, N. Lontis, F. Popescu, Z. Sümeghy, Science of the Total Environment, 2013, 458-460, 36.

18. J. Novak, K. Hilscherová, L. Landlová, P. Čupr, L. Kohút, J.P. Giesy, J. Klánová, Environment International, 2014, 63, 64.

19. F. Mirante, P. Salvador, C. Pio, C. Alves, B. Artinano, A. Caseiro, M.A. Revuelta, Atmospheric Research, 2014, 138, 278.

20. W. De Poel, S. Pintea, J. Drnec, F. Carla, R. Felici, P. Mulder, J. Elemans, W. Van Enckevort, A.E. Rowan, E. Vlieg, Surface Science, 2014, 619, 19.

21. M. S. Żbik, N.A. Raftery, R.S.C. Smart, R.L. Frost, Applied Clay Science, 2010, 50, 299.

22. O. Horovitz, Gh. Tomoaia, A. Mocanu, T. Yupsanis, M. Tomoaia-Cotisel, Gold Bulletin, 2007, 40 (4), 295.

23. M. Tomoaia-Cotisel, A. Tomoaia-Cotisel, T. Yupsanis, Gh. Tomoaia, I. Balea, A. Mocanu, Cs. Racz, Revue Roumaine de Chimie, 2006, 51 (12),1181.

24. M.A. Naghiu, M. Gorea, E. Mutch, F. Kristaly, M. Tomoaia-Cotisel, Journal of Material Science and Technology, 2013, 29 (7), 628.

25. G. Tomoaia, O. Soritau, M. Tomoaia-Cotisel, L.-B. Pop, A. Pop, A. Mocanu, O. Horovitz, L.-D. Bobos, Powder Technology, 2013, 238, 99.

26. Gh. Tomoaia, O. Horovitz, A. Mocanu, A. Nita, A. Avram, C.P. Racz, O. Soritau, M. Cenariu, M. Tomoaia-Cotisel, Colloids and Surfaces B: Biointerfaces, 2015, 135, 726.

27. P.T. Frangopol. D.A. Cadenhead, Gh. Tomoaia, A. Mocanu, M. TomoaiaCotisel, Revue Roumaine de Chimie, 2015, 60 (2-3), 265.

28. R.D. Pasca, G. Tomoaia, A. Mocanu, I. Petean, G.A. Paltinean, O. Soritau, M. Tomoaia-Cotisel, Studia Univ. Babes-Bolyai, Chemia, 2015, 60 (3), 257.

29. G. Tomoaia, A. Mocanu, L.D. Bobos, L.B. Pop, O. Horovitz, M. TomoaiaCotisel, Studia Univ. Babes-Bolyai, Chemia, 2015, 60 (3), 265.

30. G. Tomoaia, M. Tomoaia-Cotisel, L.B. Pop, A. Pop, O. Horovitz, A. Mocanu, N. Jumate, L.-D. Bobos, Revue Roumaine de Chimie, 2011, 56, 1039.

31. M. Tomoaia-Cotisel, A. Mocanu, Revista de Chimie (Bucharest), 2008, 59 (11), 1230.

32. G. Furtos, M.A. Naghiu, H. Declercq, M. Gorea, C. Prejmerean, O. Pana, M. Tomoaia-Cotisel, Journal of Biomedical Materials Research Part B. Applied Biomaterials, 2015, 104 (7), 1290. 
I. PETEAN, A. MOCANU, G. PĂLTINEAN, R. ŢĂRCAN, D. MUNTEAN, L. MUREŞAN, G. ARGHIR, M. COTIŞEL

33. F. Goga, E. Forizs, A. Avram, A. Rotaru, A. Lucian, I. Petean, A. Mocanu, M. Tomoaia-Cotisel, Revista de Chimie (Bucuresti), 2017, 68 (6), 1193.

34. I. Cojocaru, A. Tomoaia-Cotisel, A. Mocanu, T. Yupsanis, M. Tomoaia-Cotisel, Revista de Chimie (Bucuresti), 2017, 68 (7), 1470. 